\title{
Effects of a calcium phosphate cement on mineralized nodule formation compared with endodontic cements
}

\author{
Hidehiro OGATA ${ }^{1}$, Makoto HAYASHI ${ }^{1}$, Hiromasa TSUDA², Naoto SUZUKI², Masao MAENO ${ }^{3}$, \\ Akiyoshi SUGAWARA ${ }^{4}$ and Bunnai OGISO ${ }^{1}$ \\ 'Department of Endodontics, Nihon University School of Dentistry, 1-8-13 Kanda-Surugadai, Chiyoda-ku, Tokyo 101-8310, Japan \\ ${ }^{2}$ Department of Biochemistry, Nihon University School of Dentistry, 1-8-13 Kanda-Surugadai, Chiyoda-ku, Tokyo 101-8310, Japan \\ ${ }^{3}$ Department of Oral Health Sciences, Nihon University School of Dentistry, 1-8-13 Kanda-Surugadai, Chiyoda-ku, Tokyo 101-8310, Japan \\ ${ }^{4}$ Nihon University School of Dentistry, 1-8-13 Kanda-Surugadai, Chiyoda-ku, Tokyo 101-8310, Japan \\ Corresponding author, Makoto HAYASHI; E-mail: hayashi-m@dent.nihon-u.ac.jp
}

\begin{abstract}
The aim of this study was to investigate mineralizing ability of a premixed calcium phosphate cement (premixed-CPC) compared to mineral trioxide aggregate (MTA) and zinc oxide eugenol cement (SuperEBA) in ROS17/2.8 cells. The measurements of cell proliferation, alkaline phosphatase (ALPase) activity and mineralized nodule formation in the presence or absence (control) of the test materials were performed using a cell culture insert method with the test materials placed on a porous membrane of culture plate insert. Mineralized nodules were detected by staining with alizarin red, and the calcium content of the mineralized nodules was determined quantitatively using a calcium assay kit. Premixed-CPC and MTA indicated significantly higher cell proliferation, ALPase activity, mineralized nodule formation, and calcium content in nodules than those of SuperEBA $(p<0.05)$. The present results suggest that premixed-CPC has the same mineralizing ability as MTA
\end{abstract}

Keywords: Calcium phosphate cement, Endodontic cement, Biocompatibility, Mineralization

\section{INTRODUCTION}

The majority of endodontic failures occur as a result of leakage of irritants into the periapical tissues ${ }^{1-3)}$. Ideal orthograde or retrograde filling materials should seal the pathways of communication between the root canal system and its surrounding periodontal tissues ${ }^{4}$. Critical characteristics of a root-end filling or root repair material would be nontoxic, noncarcinogenic, biocompatible with the host tissues, and insoluble in tissue fluids ${ }^{5,6)}$. Furthermore, endodontic materials should be easily manipulated, have adequate working time and quick setting time, and that the presence of moisture does not affect their sealing ability.

Some examples of the endodontic materials are gutta-percha, zinc oxide eugenol-based cements, composite resin, glass ionomer cements, water settable cements, gold foil, polycarboxylate cements, polyvinyl cements, and amalgam ${ }^{1-3)}$. Unfortunately, most of them have shown different levels of weakness in biocompatibility, leakage, solubility, handling properties, moisture incompatibility, and cost. Mineral trioxide aggregate (MTA) materials developed in 1993 by Torabinejad et al.5) have overcome most of these weaknesses and have been in widespread use clinically. However, MTA has disadvantages: it does not have good handling property when this cement was prepared according to manufacturers' instructions, and the setting time of MTA is relatively long, i.e. 3 to $4 \mathrm{~h}$ after mixing ${ }^{6}$.

Calcium phosphate cements (CPC) have become useful materials in a variety of dental and medical applications because of the combination of setting properties and biocompatibility. The application of calcium phosphate materials as a bone substitute or bone graft may be traced back to Albee's report ${ }^{7}$ which described that a triple calcium phosphate compound placed in a bony defect promoted osteogenesis or new bone formation. Brown and $\mathrm{Chow}^{8}$ described that certain combinations of finely powdered calcium phosphates, when mixed with water, harden like a cement with chemical composition and crystal structures similar to that of teeth and bone. Their article is the first report about CPC consisting of equimolar amounts of tetracalcium phosphate (TTCP, $\left.\mathrm{Ca}_{4}\left(\mathrm{PO}_{4}\right)_{2} \mathrm{O}\right)$ and dicalcium phosphate anhydrous $\left(\mathrm{DCPA}, \mathrm{CaHPO}_{4}\right)$. In vitro studies and animal models have indicated that CPC was useful as a filler/sealer in root canal treatment ${ }^{9-11)}$. Sugawara et $a l .{ }^{12)}$ reported that the glycerol-CPC paste showed better biocompatibility than a number of presently used root canal filling or sealing materials. Takagi et al. ${ }^{13)}$ also reported the feasibility of formulating premixed-CPCs that are stable in a package, resist washout, and will harden only after being delivered to the defect site. Glycerol was used as the liquid because the $\mathrm{CPC}$ hardening reaction does not occur in a water-free glycerol environment. Hydroxypropyl methylcellulose (HMC) and $\mathrm{Na}_{2} \mathrm{HPO}_{4}$ (disodium hydrogen phosphate) was added to improve the paste cohesiveness and accelerate cement hardening, respectively. This premixed-CPC exhibited good handling properties, set in an aqueous environment, and formed hydroxyapatite as the final product ${ }^{13}$. The results of a preliminary in vivo study using a rabbit model showed that the material had good biocompatibility ${ }^{14)}$.

The above results suggest that the premixed-CPC has many desirable properties as a root-end filling or 
root repair material, and it may overcome the disadvantages of MTA. Because there have been no studies comparing cultured osteoblastic cell activities on premixed-CPC and other endodontic materials. This study was conducted to analyze cell proliferation, alkaline phosphatase (ALPase) activity and mineralized nodule formation of a premixed-CPC as a new root-endfilling or root repair material with MTA as the gold standard control.

\section{MATERIALS AND METHODS}

\section{Cell culture}

The rat clonal cell line ROS $17 / 2.8$ was used as the osteoblasts in this study. The cells were maintained in a growth medium consisting of $\alpha$-minimal essential medium ( $\alpha$-MEM; Gibco BRL, Rockville, MD, USA) containing 10 volume fraction \% heat-inactivated fetal bovine serum (FBS; HyClone Laboratories, Logan, UT, USA) and 1\% volume fraction penicillin-streptomycinneomycin solution (PSN; Sigma Chemical, St. Louis, $\mathrm{MO}, \mathrm{USA}$ ) at $37^{\circ} \mathrm{C}$ in a humidified atmosphere of $95 \%$ air and $5 \% \mathrm{CO}_{2}$.

\section{Preparation of test materials}

Test materials used in this study (Table 1) were a premixed-CPC (courtesy of Drs. Laurence Chow and Shozo Takagi, Paffenbarger Research Center, ADAF at NIST, MD, USA), MTA (ProRoot ${ }^{\circledR}$ MTA, Dentsply Tulsa, TN, USA) and eugenol-based cements (SuperEBA, Harry J. Boworth Company, IL, USA). The premixed-CPC was prepared by mixing of equimolar amounts of TTCP and DCPA with a glycerol liquid that contained 30 mass fraction \% $\mathrm{Na}_{2} \mathrm{HPO}_{4}$ (Wako Pure Chemical Industries Ltd., Osaka, Japan) and 0.55 mass fraction \% HMC (Wako Pure Chemical Industries Ltd.) at a powder-toliquid mass ratio of 4 as previously described ${ }^{13)}$. MTA and eugenol-based cements were prepared according to manufacturers' instructions.
Each pellet ( $3 \mathrm{~mm}$ diameter and $0.5 \mathrm{~mm}$ thickness) was allowed to set for $24 \mathrm{~h}$ at $37^{\circ} \mathrm{C}$ in $100 \%$ humidity, and placed in $\alpha$-MEM $(0.7 \mathrm{~mL})$ for 3 days as previously described by Haglund et al. ${ }^{15)}$, Saidon et al. ${ }^{16)}$ and Takita et $a l .{ }^{17)}$.

\section{Determination of cell proliferation}

The measurement of cell proliferation in the presence of the test materials was performed using 24-well cell culture plates, and each well had a culture plate insert with a porous bottom ( $3 \mu \mathrm{m}$ pore size) (BD Falcon, Franklin Lakes, NJ, USA). ROS 17/2.8 were seeded onto the plates at an initial density of approximately $2.0 \times 10^{4}$ cells per well in $0.5 \mathrm{~mL} \alpha$-MEM containing 10 volume fraction \% FBS. The cells were incubated for $24 \mathrm{~h}$ to allow adhesion, and then a culture plate insert with one pellet of the test material was placed into each well (Fig. 1). Cells cultured without test material served as the negative control. The number of cells was determined using a Cell Counting kit 8 (Dojindo Molecular

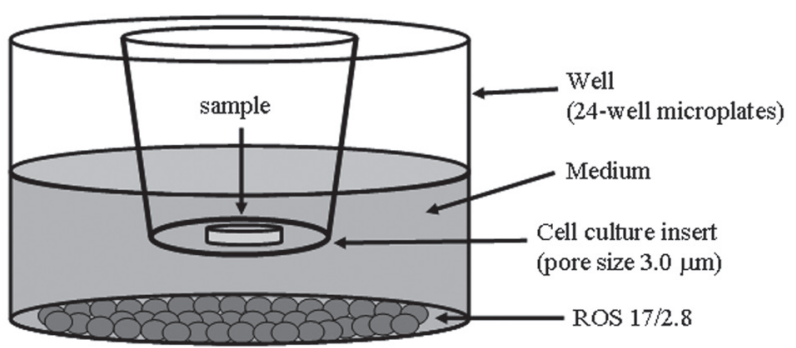

Fig. 1 Schematic representation showing the culture plate with cell culture insert. Cell culture insert: samples were placed. Well (24-well microplates): ROS17/2.8 were incubated for $24 \mathrm{~h}$ to allow adhesion, and then a culture plate insert with one pellet of test material was placed into each well.

Table 1 Materials used in this study

\begin{tabular}{|c|c|c|}
\hline Material (manufacturer) & & Composition \\
\hline \multirow[t]{2}{*}{$\begin{array}{l}\text { Premixed-CPC (courtesy from Paffenbarger Research Center, } \\
\text { ADAF at NIST, Maryland, USA) }\end{array}$} & Paste & $\begin{array}{l}\text { Tetracalcium phosphate, dicalcium } \\
\text { phosphate anhydrous, glycerol, } \\
\text { hydroxypropyl methylcellulose, disodium } \\
\text { hydrogen phosphate }\end{array}$ \\
\hline & Liquid & Distilled water \\
\hline \multirow[t]{2}{*}{ MTA (ProRoot ${ }^{\mathbb{R}}$ MTA, Dentsply Tulsa, Tennessee, USA) } & Powder & $\begin{array}{l}\text { Tricalcium silicate, bismuth oxide, } \\
\text { dicalcium silicate, tricalcium aluminate, } \\
\text { calcium sulfate dehydrate or gypsum }\end{array}$ \\
\hline & Liquid & Distilled water \\
\hline \multirow[t]{2}{*}{$\begin{array}{l}\text { Eugenol-based cements (SuperEBA, Harry J. Boworth Company, } \\
\text { Illinois, USA) }\end{array}$} & Powder & $\begin{array}{l}\text { Zic oxide } 60 \% \text {, alumina } 34 \% \text {, } \\
\text { natural resin } 6 \%\end{array}$ \\
\hline & Liquid & $\begin{array}{l}\text { Ortho ethoxy, benzoic acid } 62.5 \% \text {, } \\
\text { eugenol } 37.5 \%\end{array}$ \\
\hline
\end{tabular}


Technologies Inc., Kumamoto, Japan) at 3, 5, 7 and 9 days. At the specified time periods, the medium was replaced with fresh medium containing 10 volume fraction \% Cell Counting reagent, and the incubation continued for $1 \mathrm{~h}$. After incubation, the absorbance of the reaction products was measured at $450 \mathrm{~nm}$ with a microtitre plate reader (Titertec Multiskan Plus, Flow Laboratory, McLean, VA, USA). The cell number was calculated from the absorbance value relative to a standard curve ${ }^{18)}$.

\section{Determination of ALPase activity}

The cells were plated on 24-well microplates at a density of $2 \times 10^{4}$ cells/well for up to 12 days. Two hundred microlitres of enzyme assay solution ( $8 \mathrm{mM}$ p-nitrophenyl phosphate, $12 \mathrm{mM} \mathrm{MgCl}_{2}, 0.1 \mathrm{mM} \mathrm{ZnCl}_{2}, 0.1 \mathrm{M}$ glycine- $\mathrm{NaOH}$ buffer ( $\mathrm{pH}$ 10.5) $)^{19)}$ were added to the cells in each well, and the plate was incubated for several minutes at $37^{\circ} \mathrm{C}$. The enzyme reaction was terminated by the addition of $50 \mathrm{~mL}$ of $0.1 \mathrm{M} \mathrm{NaOH}$. The amount of $p$-nitrophenol released by the enzymatic reaction was determined by measuring the absorbance at $405 \mathrm{~nm}$ in the microtiter plate reader. One unit of ALPase activity was defined as the amount required for the liberation of $1.0 \mu \mathrm{mol} p$-nitrophenol/min. The enzyme activity was recorded as milliunits $(\mathrm{mU}) / 10^{4}$ cells ${ }^{19)}$.

\section{Determination of mineralized nodule formation}

The cells were plated in 24-well tissue culture plates at a density of $1.25 \times 10^{5}$ cells/well and cultured in ROS17/2.8 with $50 \mathrm{mM} \beta$-glycerophosphate $(\beta$-GP) and $50 \mu \mathrm{g} / \mathrm{mL}$ ascorbic acid (AA) for up to 11 days to assess mineralized nodule formation as a function of osteogenic behavior ${ }^{19}$. The culture medium was changed every second or third day. The condition of the cells and nodule formation were checked routinely by phase-contrast microscopy (Nikon DIAPHOT, Nikon Co., Tokyo, Japan). Mineralized nodules were detected by staining with Alizarin Red S (Wako Pure Chemical Industries Ltd.), as described previously ${ }^{19)}$.

\section{Determination of calcium and protein content}

The cells were plated in 24-well tissue culture plates at a density of $1.25 \times 10^{5}$ cells/well and cultured in ROS17/2.8 with $50 \mathrm{mM} \beta$-GP and $50 \mu \mathrm{g} / \mathrm{mL}$ AA for 11 days $^{19)}$, at which time the medium was discarded, $300 \mu \mathrm{L}$ of $0.5 \mathrm{M}$ $\mathrm{HCl}$ was added to each well, and the cells were incubated overnight to decalcify the mineralized nodules. The calcium content was determined quantitatively using the Calcium E-Test Kit (Wako Pure Chemical Industries Ltd., Osaka, Japan). The protein content was determined quantitatively using the protein assay solution (Bio-Rad Laboratories, Hercules, CA, USA) after evaporation of the $\mathrm{HCl}$ from the samples ${ }^{17)}$.

\section{Statistical analysis}

All experiments were performed in triplicate. Each value represents the mean \pm standard deviation (SD). In this study, the SD is considered to be the standard uncertainty of the measurements. The significance $(p<0.05)$ of differences among the groups was determined using ANOVA test followed by Student-Newman-Keuls Test.

\section{RESULTS}

\section{Cell proliferation}

Figure 2 shows cell proliferation of ROS17/2.8 after exposure to premixed-CPC, MTA and SuperEBA for 3, 5, 7, and 9 days. Premixed-CPC, MTA and the control indicated significantly higher cell proliferation than SuperEBA $(p<0.05)$. There were no significant difference among premixed-CPC, MTA and the control.

\section{ALPase activity}

Figure 3 shows the ALPase activity at 5, 7, and 9 days. There were no significant difference among premixedCPC, MTA, and the control at each experimental point except for 3 days culture. SuperEBA showed significantly $(p<0.05)$ lower ALPase activity at all time points.

\section{Mineralized nodule formation}

Figure 4 shows the mineralized nodule formation, as confirmed by Alizarin Red S staining, of test materials for up to 11 days of culture. In the control, premixedCPC, and MTA groups, mineral deposits were detectable with the naked eye in the 7-day culture. The mineralized nodules enlarged between 9 days and 11 days.

In contrast, in the presence of SuperEBA, the appearance of staining of mineralized nodules by Alizarin Red S did not occur throughout the experimental period. The intensity of Alizarin Red S staining was clearly lower than those in the other three groups.

\section{Calcium and protein content}

Figure 5 shows the $\mathrm{Ca} /$ protein ratios of the mineralized nodules of the 11 days culture in the presence or absence of the test materials. The ratios in control, premixed-CPC

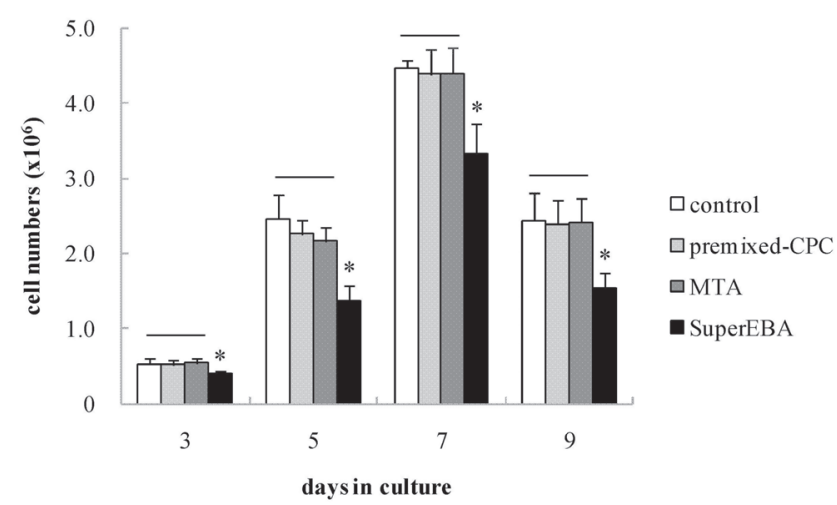

Fig. 2 Premixed-CPC, MTA, and SuperEBA on the cell proliferation of ROS17/2.8 cells. Cell proliferation viability of ROS17/2.8 after 3, 5, 7, and 9 days were determined by Cell Counting Kit 8. Each value represents mean $\pm \mathrm{SD}$ of 3 independent experiments. Values connected by a horizontal line are not significantly $(p>0.05)$ different. *Significantly lower $(p<0.05)$. 


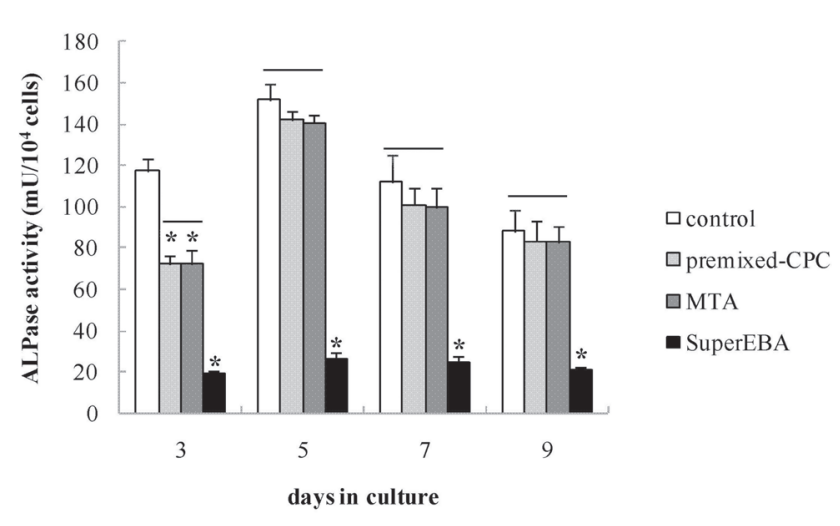

Fig. 3 Premixed-CPC, MTA, and SuperEBA on the alkaline phosphatase (ALPase) activity of ROS17/2.8 cells. ALPase activity of ROS17/2.8 after $3,5,7$, and 9 days. The amount of $p$-nitrophenol released by the enzymatic reaction was determined by measuring the absorbance at $405 \mathrm{~nm}$ in the microtiter plate reader. Each value represents mean \pm SD of 3 independent experiments. Values connected by a horizontal line are not significantly $(p>0.05)$ different. *Significantly lower $(p<0.05)$.

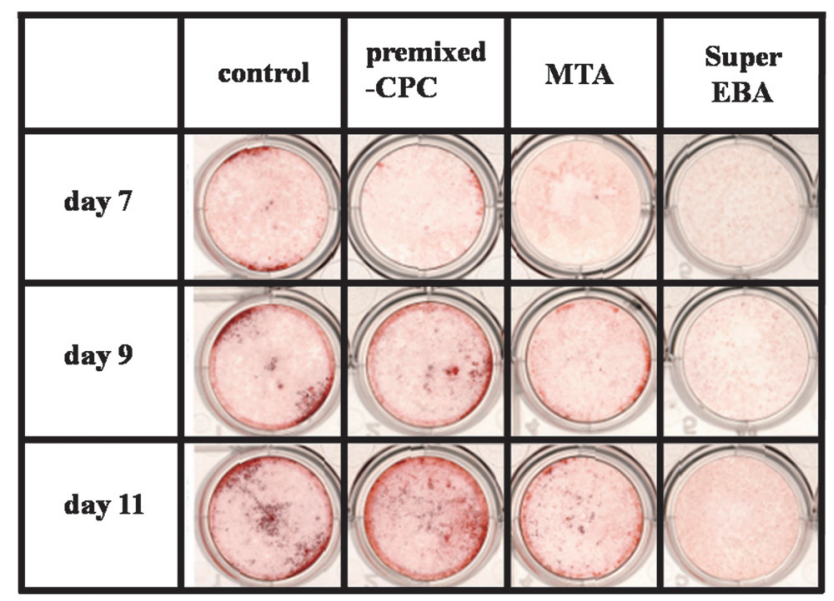

Fig. 4 Premixed-CPC, MTA, and SuperEBA on the mineralized nodule formation of ROS17/2.8 cells. Mineralized nodules were detected by staining with Alizarin Red S.

and MTA groups were not significantly different $(p<0.05)$. However, the ratio in SuperEBA was significantly lower than those of the other three groups.

\section{DISCUSSION}

The aim of this study was to evaluate osteoblast-like cell response to premixed-CPC on proliferation, mineralization and ALPase activity, as compared with other endodontic materials. Our results showed that premixed-CPC has the same characteristics as those of

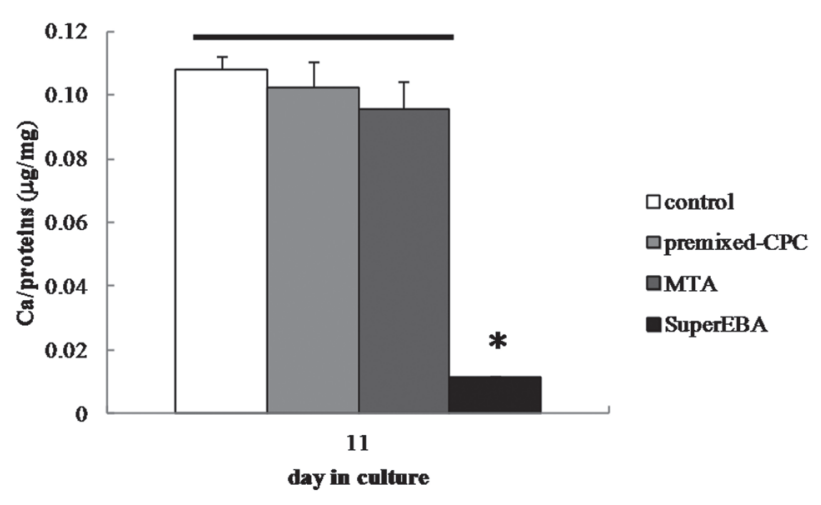

Fig. 5 Premixed-CPC, MTA, and SuperEBA on calcium and protein content of ROS17/2.8 cells. The calcium content was determined by the Calcium E-Test Kit. The protein content was determined by the protein assay solution. Each value represents mean $\pm \mathrm{SD}$ of 3 independent experiments. Values connected by a horizontal line are not significantly $(p>0.05)$ different. *Significantly lower $(p<0.05)$.

the control and MTA. Previous studies using various cell culture systems have shown that MTA is one of the least cytotoxic dental materials ${ }^{20-23)}$. Similarly, premixed-CPC has been reported to have excellent biocompactibility due to the fact that premixed-CPC was nearly completely converted to hydroxyapatite (HA) within $24 \mathrm{~h}$ in an aqueous environment ${ }^{24)}$. The present results are consistent with these previous findings, showing that there were no significant differences among premixedCPC, MTA and control in nearly all tests. In contrast, the results showed that SuperEBA exhibited cytotoxicity. SuperEBA cement consists of a powder containing zinc oxide (60-75\%), fused quartz or alumina (20-35\%) and hydrogenated resin (6\%), and a liquid containing of $63 \%$ ethoxybenzoic acid (EBA) and 37\% eugenol. The EBA encourages the formation of a crystalline structure that improves the strength of the material ${ }^{25}$. The zinc oxideeugenol cements are generally inclined to cause inflammatory reactions in the tissues, mainly due to the cytotoxic effect of eugenol ${ }^{26}$. Eugenol has been widely used as an antimicrobial and anti-inflammatory agent; however, previous in vivo and in vitro studies have demonstrated its toxic affects ${ }^{27-31}$. It has been reported that eugenol inhibits mitochondrial activity ${ }^{29-31}$. It also alters the cell membrance ${ }^{29)}$ and stimulates the neutrophils ${ }^{30,32)}$.

ALPase activity, which is closely related to new bone formation, was used as a measure of osteoconductivity of the test material. Sugawara et al. ${ }^{12)}$ showed that CPC exhibited a much higher ALPase activity than the control. However, our results showed that premixedCPC, MTA and control cells indicated no significant difference at each experimental point except for the 3 -day culture. One possible reason for the different 
results is that we used a premixed-CPC whereas a conventional powder-and-liquid CPC was used in Sugawara et al. ${ }^{12)}$. Other possible reasons include the differences in the type of cells used, the conditions for preparing the test materials, and the test material-toculture medium ratio. It is noted that in the present study the test specimens were allowed to set for $24 \mathrm{~h}$ at $37^{\circ} \mathrm{C}$ in $100 \%$ humidity, and then immersed for 3 days in $\alpha$-MEM prior to cell culture. The previous tissue culture studies have focused on the cytotoxicity of endodontic materials in the freshly mixed state before setting ${ }^{15)}$. When freshly mixed, these materials release a host of chemical by-products that are cytotoxic to the cells in the culture. Under clinical conditions, however, these by-products are diluted in the interstitial tissue fluids and are eliminated through the vasculature. Therefore, recent studies have examined the effect of preset, washed materials on cells. Thus, any cytotoxic effects observed on these pre-conditioned samples would suggest persisting tissue incompatibility.

The mineralized nodule formation of osteoblast increased gradually between 7 days and 11 days in the control, premixed-CPC and MTA groups (Fig. 4). Hence, the determination of the amount of calcium and protein content was focused on the maximum nodules formation i.e. 11-day culture. This result showed that the control, premixed-CPC, and MTA were not significant different (Fig. 5). Therefore, it may indicate that both test materials did not inhibit in vitro mineralization of osteoblast, and are more biocompatible than SuperEBA.

Human mesenchymal stem cells (hMSC) showed excellent attachment and viability on $\mathrm{CPC}^{33)}$, and MTA was able to assist hMSC adhesion, growth, and migration $^{34)}$. Although there are no published reports comparing the response of hMSC to the two materials, it may be expected that CPC has the same levels of biocompatibility as that of MTA to hMSC, besides osteoblasts.

The cell culture system used in this study was designed to evaluate the effect of test materials using cell culture inserts to prevent direct physical interactions between materials and cells. This system raises the possibility of chemical reaction between the components that diffuse from test materials and the elements of $\alpha$-MEM. However, all test materials were allowed to set for $24 \mathrm{~h}$ in $100 \%$ humidity, and placed in $\alpha$-MEM for 3 days before using them. Premixed-CPC may be converted to stable HA in such condition, therefore, no component may be released from this material to $\alpha$-MEM. Whereas, some investigators have reported that calcium ions were released from MTA to medium ${ }^{17,35)}$. Because $\alpha$-MEM already contains calcium ion, which is one of the important elements for in vitro cell culture, calcium ions released from MTA may not chemically affect other elements of $\alpha$-MEM.

The premixed-CPC exhibited extremely good handling characteristics, which greatly facilitated sample preparation. Under clinical conditions, premixed pastes would shorten surgical time, avoid insufficient or inhomogeneous mixing, and improve the implant performance by mixing the paste in advance under wellcontrolled conditions. The results obtained from this in vitro study suggest that premixed-CPC could be used as an endodontic cement not only because of its good handling properties and shorter hardening time than MTA but also because of its good mineralization effects.

\section{ACKNOWLEDGMENTS}

The authors gratefully thank Drs. Laurence Chung-Lung Chow and Shozo Takagi, Paffenbarger Research Center, ADAF at NIST, Maryland, USA for their valuable support. This research work was financially supported by a Grant-in-Aid for Scientific Research (C) from the Japan Society for Promotion of Science (M.H.).

\section{REFERENCES}

1) Johnson BR, Witherspoon DE. In: Cohen S, Hargreaves K, editors. Pathways of the pulp. 9th ed. St. Louis: Mosby Elsevier; 2011. p. 720-776.

2) Gartner AH, Drone SO. Advances in endodontic surgery. Dent Clin North Am 1992; 36: 357-379.

3) Xavier CB, Weismann R, de Oliveira MG, Demarco FF, Pozza DH. Root-end filling materials: apical microleakage and marginal adaptation. J Endod 2005; 31: 539-542.

4) Chng HK, Islam I, Yap AU, Tong YW, Koh ET. Properties of a new root-end filling material. J Endod 2005; 31: 665-668.

5) Torabinejad M, Watson TF, Pitt Ford TR. Sealing ability of a mineral trioxide aggregate when used as a root end filling material. J Endod 1993; 19: 591-595.

6) Torabinejad M, Hong CU, McDonald F, Pitt Ford TR. Physical and chemical properties of a new root-filling material. $\mathrm{J}$ Endod 1995; 21: 349-353.

7) Albee FH. Studies in bone growth: Triple calcium phosphate as a stimulus to osteogenesis. Ann Surg 1920; 71: 32-39.

8) Brown WE, Chow LC. A new calcium phosphate water setting cement. Cem Res Prog 1986; 352-379.

9) Hong YC, Wang JT, Hong CY, Brown WE, Chow LC. The periapical tissue reactions to a calcium phosphate cement in the teeth of monkeys. J Biomed Mater Res 1991; 25: 485-498.

10) Sugawara A, Chow LC, Takagi S, Chohayeb H. In vitro evaluation of the sealing ability of a calcium phosphate cement when used as a root canal sealer-filler. J Endod 1990; 16: 162-165.

11) Cherng AM, Chow LC, Takagi S. In vitro evaluation of a calcium phosphate cement root canal filler/sealer. J Endod 2001; 27: 613-615.

12) Sugawara A, Fujikawa K, Takagi S, Chow LC, Nishiyama M, Murai S. Histopathological and cell enzyme studies of calcium phosphate cements. Dent Mater J 2004; 23: 613-620.

13) Takagi S, Chow LC, Hirayama S, Sugawara A. Premixed calcium-phosphate cement pastes. J Biomed Mater Res B Appl Biomater 2003; 67: 689-696.

14) Sugawara A, Fujikawa K, Hirayama S, Takagi S, Chow LC. In vivo Characteristics of premixed calcium phosphate cements when implanted in subcutaneous tissues and periodontal bone defects. J Res Natl Inst Stand Technol 2010; 115: 277-290.

15) Haglund R, He J, Jarvis J, Safavi KE, Spångberg LS, Zhu Q. Effects of root-end filling materials on fibroblasts and macrophages in vitro. Oral Surg Oral Med Oral Pathol Oral Radiol Endod 2003; 95: 739-745.

16) Saidon J, He J, Zhu Q, Safavi K, Spångberg LS. Cell and tissue reactions to mineral trioxide aggregate and portland cement. Oral Surg Oral Med Oral Pathol Oral Radiol Endod 
2003; 95: 483-489.

17) Takita T, Hayashi M, Takeichi O, Ogiso B, Suzuki N, Otsuka $\mathrm{K}$, Ito K. Effect of mineral trioxide aggregate on proliferation of cultured human dental pulp cells. Int Endod J 2006; 39: 415-422.

18) Shimizu E, Nakajima Y, Kato N, Nakayama $Y$, Saito R, Samoto H, Ogata Y. Regulation of rat bone sialoprotein gene transcription by enamel matrix derivative. J Periodontol 2004; 75: 260-267.

19) Katono T, Kawato T, Tanabe N, Suzuki N, Iida T, Morozumi A, Ochiai K, Maeno M. Sodium butyrate stimulates mineralized nodule formation and osteoprotegerin expression by human osteoblasts. Arch Oral Biol 2008; 53: 903-909.

20) Torabinejad M, Hong CU, Pitt Ford TR, Kettering JD. Cytotoxicity of four root end filling materials. J Endod 1995; 21: 489-492.

21) Osorio RM, Hefti A, Vertucci FJ, Shawley AL. Cytotoxicity of endodontic materials. J Endod 1998; 24: 91-96.

22) Keiser K, Johnson CC, Tipton DA. Cytotoxicity of mineral trioxide aggregate using human periodontal ligament fibroblasts. J Endod 2000; 26: 288-291.

23) Gorduysus M, Avcu N, Gorduysus O, Pekel A, Baran Y, Avcu F, Ural AU. Cytotoxic effects of four different endodontic materials in human periodontal ligament fibroblasts. J Endod 2007; 33: 1450-1454.

24) Sugawara A, Fujikawa K, Kusama K, Nishiyama M, Murai S, Takagi S, Chow LC. Histopathologic reaction of a calcium phosphate cement for alveolar ridge augmentation. J Biomed Mater Res 2002; 61: 47-52.

25) Koulaouzidou EA, Economides N, Beltes P, Geromichalos G, Papazisis K. In vitro evaluation of the cytotoxicity of ProRoot MTA and MTA Angelus. J Oral Sci 2008; 50: 397-402.

26) Gulati N, Chandra S, Aggarwal PK, Jaiswal JN, Singh M.
Cytotoxicity of eugenol in sealer containing zinc-oxide. Endod Dent Traumatol 1991; 7: 181-185.

27) Kasugai S, Hasegawa N, Ogura H. Application of the MTT colorimetric assay to measure cytotoxic effects of phenolic compounds on established rat dental pulp cells. J Dent Res 1991; 70: 127-130.

28) Ho YC, Huang FM, Chang YC. Mechanisms of cytotoxicity of eugenol in human osteoblastic cells in vitro. Int Endod $\mathrm{J}$ 2006; 39: 389-393.

29) Fujisawa S, Kadoma Y, Komoda Y. $1 \mathrm{H}$ and $13 \mathrm{C}$ NMR studies of the interaction of eugenol, phenol, and triethyleneglycol dimethacrylate with phospholipid liposomes as a model system for odontoblast membranes. J Dent Res 1988; 67: 1438-1441.

30) Hume WR. In vitro studies on the local pharmacodynamics, pharmacology and toxicology of eugenol and zinc oxideeugenol. Int Endod J 1988; 21: 130-134.

31) Gerosa R, Borin M, Menegazzi G, Puttini M, Cavalleri G. In vitro evaluation of the cytotoxicity of pure eugenol. J Endod 1996; 22: 532-534.

32) McDonald JW, Heffner JE. Eugenol causes oxidant-mediated edema in isolated perfused rabbit lungs. Am Rev Respir Dis 1991; 143: 806-809.

33) Weir MD, Xu HH. Culture human mesenchymal stem cells with calcium phosphate cement scaffolds for bone repair. J Biomed Mater Res B Appl Biomater 2010; 93: 93-105.

34) D'Antò V, Di Caprio MP, Ametrano G, Simeone M, Rengo S, Spagnuolo G. Effect of mineral trioxide aggregate on mesenchymal stem cells. J Endod 2010; 36: 1839-1843.

35) Maeda H, Nakano T, Tomokiyo A, Fujii S, Wada N, Monnouchi $\mathrm{S}$, Hori K, Akamine A. Mineral trioxide aggregate induces bone morphogenic protein-2 expression and calcification in human periodontal ligament cells. J Endod 2010; 36: 647-652. 